\title{
SOIL PROPERTIES AND GROWTH PERFORMANCE OF RIZE (Oryza sativa L.) GROWN IN A FLY-ASH AMENDED SOIL
}

\author{
Bambang J. Priatmadi ${ }^{1}$, Akhmad R. Saidy ${ }^{2}$, and Meldia Septiana ${ }^{3}$ \\ ${ }^{1}$ Department of Soil, Faculty of Agriculture, Lambung Mangkurat University. Jalan A. Yani Km 6 \\ Simpang Empat Banjarbaru, South Kalimantan, Indonesia. Tel./Fax. 0511-4 4773112/4782899, \\ 2email address: asaidy@unlam.ac.id
}

\begin{abstract}
Fly-ash (FA) is largely alkaline in nature and contains many essential elements for plant growth along with toxic metals. Therefore, fly-ash is potential to be applied as soil ameliorate that may improve soil properties and plant growth. In this experiment we studied the changes in chemical properties and rice production of acid sulphate soils amended with fly ash. Six different amounts of FA, viz. 0 (100\% soil), 5, 10, 20, 40 and 75 tones FA ha ${ }^{-1}$ were added homogenously to $6 \mathrm{~kg}$ of soils in pots of PVC and then chemical properties of acid sulphate soils were observed after a 3-week of incubation. Subsequent of the observation of soil properties, rice was planted onto the pots. Results of study showed that fly-ash application improved soil $\mathrm{pH}$ and exchangeable $\mathrm{Ca}$. However, the availability of nitrogen of acid sulphate soils decreased significantly with fly-ash application. The experiment also showed that fly-ash application to soils improved rice growth (height plant, number of tillers, dried-weight root and dried-weight shoot) and rice production. Application 20 tones FA ha ${ }^{-1}$ resulted in higher rice production than the application 0,5 and 10 tones FA ha ${ }^{-1}$, and increasing subsequent the amount of FA application did not significantly increase the rice production. Results of this study demonstrate that low-level fly-ash application resulted in the improvements of soil chemical properties and rice production.
\end{abstract}

Key words: fly-ash application; soil ameliorant; heavy metals; sub-optimal low land

\section{INTRODUCTION}

Main problem in rice cultivation in acid sulphate soils is low productivity. Data from the Department of Agriculture, South Kalimantan (2007) showed that rice production in acid sulphate soils ranged from
3.14 to 4.30 tonnes per hectare. One of the factors limiting the growth of rice in acid sulphate soils is low soil $\mathrm{pH}$. The observations in the province of South Kalimantan showed that the $\mathrm{pH}\left(\mathrm{H}_{2} \mathrm{O}\right)$ of the acid sulphate soils ranged between 3.96 and 4.88 (Saidy et al., 2005). Low soil pH results in low availability of soil phosphorus, calcium, magnesium, potassium and sodium (Bohn et al., 2001), and this condition eventually result in unhealthy plant growth. Improvements soil properties can be done by adding ameliorant material into the soil to increase soil $\mathrm{pH}$ and simultaneously improve the content of some nutrients such as $\mathrm{Na}, \mathrm{Ca}, \mathrm{K}$ and $\mathrm{Mg}$.

Fly ash (FA), a coal combustion residue, is an amorphous ferroalumino silicate with a matrix very similar to soil. Elemental composition of FA (both nutrient and toxic elements) varies due to types and sources of used coal (Comberato et al., 1997). Addition of FA to soil may improve the physico-chemical properties as well as nutritional quality of the soil and the extent of change depends on soil and FA properties. In view of the high cost of disposal and environmental management, utilization of $F A$ in agricultural sector could be a viable option. Its use in agriculture was initially due to its liming potential and the presence of essential nutrients, which promoted plant growth and also alleviated the nutrient deficiency in soils (Mittra et al., 2005).

The disposal of fly-ash (FA) from coalfired power stations causes significant economic and environmental problems. Dumped FA may adversely affect the environment by mobilization of its hazardous constituents and thus contaminate the surface and ground waters, soils and vegetation. Fly-ash is largely alkaline in nature and contains many essential elements like $\mathrm{Si}, \mathrm{S}, \mathrm{B}, \mathrm{Ca}, \mathrm{Mg}, \mathrm{Fe}, \mathrm{Cu}, \mathrm{Zn}, \mathrm{Mn}$ and $\mathrm{P}$. Therefore, FA may be applied to soils as soil amendment to improve soil properties and thereby enhance plant growth and productivity. However, there is a lack of evidence the use of fly-ash as soil 
amendment. In this study, we examined the effect of fly-ash application on changes in chemical properties and rice production on acid sulphate soils.

\section{MATERIALS AND METHODS}

\section{Experimental Sites}

Fly-ash used for the experiment was collected from the Asam-asam Steam Power Plant, South Kalimantan Province, Indonesia while soils for mixing with FA were obtained from the Desa Tinggirian II Luar, Kecamatan Tamban, Kabupaten Barito Kuala, South Kalimantan. Selected properties of acid sulphate soils used for this study are presented in Table 1.

\section{Greenhouse Experiment}

Six levels of amendments of FA, viz. 0 (100\% soil), $5,10,20,40$ and 75 tones FA $\mathrm{ha}^{-1}$ were added homogenously to $6 \mathrm{~kg}$ of soils in pots of PVC and then incubated for 3 weeks. After 3 weeks soils in the pots were sub-sampled and analyzed for $\mathrm{pH}$, exchangeable bases ( $\mathrm{Na}, \mathrm{K}, \mathrm{Ca}$ dan $\mathrm{Mg}$ ), mineral nitrogen, and available P. The usual farm practice of transplantation of 20-30 days old seedlings, grown in a separate seedbed, was done at three seedlings per pot. Rice plants were kept in natural conditions and irrigated with tap water to maintain waterlogged conditions and avoiding leakage of water from pots. All the growth and yield attributing characters were studied after the harvesting period of 120 days. Plant height (cm) was measured by a metric scale and number of tillers was counted manually. After this, plant parts were partitioned into roots, leaves, straw and grains and then were washed with double distilled water. Root biomass $\left(\mathrm{g} \mathrm{pot}^{-1}\right)$, straw weight $\left(\mathrm{g} \mathrm{pot}^{-1}\right)$ and total grain weight $\left(\mathrm{g} \mathrm{pot}^{-1}\right)$ were determined on oven-dried at $60^{\circ} \mathrm{C}$ basis.

Table 1. Selected physical and chemical properties of acid sulphate soils used for the study

\begin{tabular}{|c|c|}
\hline \multicolumn{2}{|l|}{ Texture } \\
\hline - Sand (\%) & 24.23 \\
\hline - Silt (\%) & 39.21 \\
\hline - Clay (\%) & 36.56 \\
\hline Bulk density $\left(\mathrm{g} \mathrm{cm}^{-3}\right)$ & 0.55 \\
\hline $\mathrm{pH}\left(\mathrm{H}_{2} \mathrm{O}\right)$ & 3.98 \\
\hline $\mathrm{pH}(\mathrm{KCl} 1 \mathrm{~N})$ & 3.67 \\
\hline Organic C ( $\mathrm{g} \mathrm{C} \mathrm{kg}^{-1}$ soil) & 27.67 \\
\hline Total nitrogen ( $\mathrm{g} \mathrm{N} \mathrm{kg}^{-1}$ soil) & 1.42 \\
\hline \multicolumn{2}{|c|}{ Exchangeable bases ( $\mathrm{cmol} \mathrm{kg}^{-1}$ soil) } \\
\hline$-\mathrm{Na}$ & 0.13 \\
\hline$-\mathrm{K}$ & 0.09 \\
\hline$-\mathrm{Ca}$ & 4.51 \\
\hline$-\mathrm{Mg}$ & 0.14 \\
\hline CEC (cmol kg-1 soil) & 29.24 \\
\hline Total Al (mg kg-1) & 1245.80 \\
\hline Total Fe (mg kg-1) & 4916.17 \\
\hline Total Mn (mg kg-1) & 175.65 \\
\hline
\end{tabular}

\section{Data Analysis}

The ANOVA procedure of GenStat $11^{\text {th }}$ Edition (Payne, 2008) was used to determine the effect of treatment on changes in the chemical properties and plant growth and production. In the case of significance in ANOVAs, means were compared by the Least Significant Difference (LSD) multiple comparison procedure at $\mathrm{P}<0.05$.

\section{RESULTS AND DISCUSSION}

\section{Changes in Soil Properties}

Results of analysis of variance showed that soil $\mathrm{pH}$, mineral nitrogen content and the concentration of exchangeable $\mathrm{Ca}$ were significantly affected by the addition of flyash. In contrast, fly-ash application to acid sulphate soils did not change the content of exchangeable $\mathrm{Na}, \mathrm{K}$ and $\mathrm{Mg}$, and available $P$.

Soil reaction (soil $\mathrm{pH}$ ) in the soil without fly-ash application was 5.08, increased to 5.31-5.48 with the application fly-ash 5-40 tonnes ha-1 (Figure 1). The soil $\mathrm{pH}$ reached to 5.62 with when the amount of fly-ash application was increased to 75 tonnes ha $^{-1}$ (Figure 1). However, the soil pH at 75 
tonnes $\mathrm{ha}^{-1}$ of fly-ash application was not significantly different to those at 20 dan 40 tonnes of fly-ash aplication (Figure 1).

Increased soil $\mathrm{pH}$ occurs because flyash containing $\mathrm{CaO}$ and $\mathrm{MgO}$, which reacted with $\mathrm{H}^{+}$ions to neutralize soil acidity. The greater the amount of fly-ash application, the greater the amount of $\mathrm{CaO}$ and $\mathrm{MgO}$ are given into the soils, thus the greater the change in soil pH. Kishor et al. (2009) reported that the neutralization capacity of fly-ash ranged from 0.01 to 3.74 meq per gram $\mathrm{H}_{3} \mathrm{O}^{+}$. Increasing the $\mathrm{pH}$ of the soil in paddy soils treated with fly-ash was also reported in several other studies (Clark et al., 2001; Hyup et al., 2006; Swain et al., 2007; Sajwan et al., 2007).

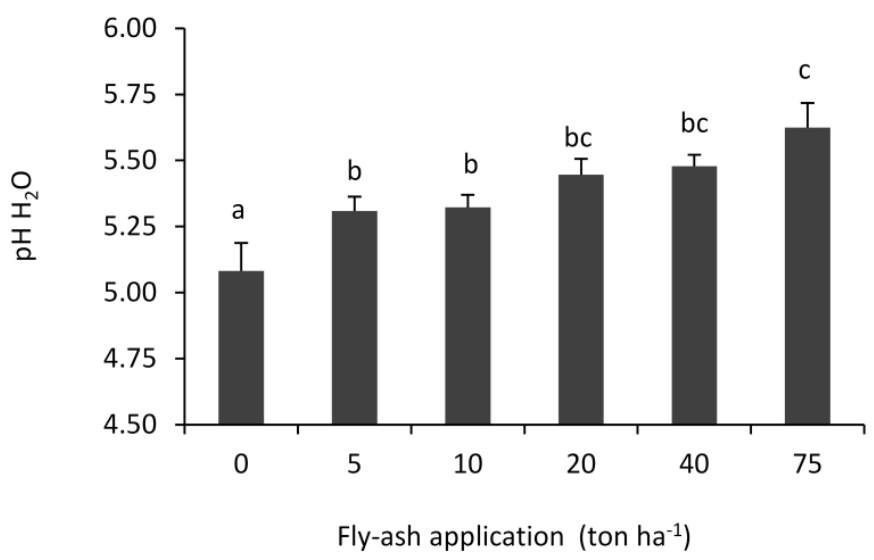

Figure 1. Effect of fly-ash application on soil $\mathrm{pH}$. The vertical bars represent standard deviation $(n=5)$. Similar letters above columns indicate no statistical difference between the treatments based on the LSD test at $P<0.05$.

Figure 2 reveals that the fly-ash application of 20 tonnes $\mathrm{ha}^{-1}$ yielded exchangeable $\mathrm{Ca}$ that is not different from the soil without fly-ash application. However, when the amount of fly-ash application increased to 40 and 75 tonnes $\mathrm{ha}^{-1}$, the concentration of exchangeable doubled than the soils without fly-ash application (control), which only reached to $15 \mathrm{cmol} \mathrm{kg}^{-1}$. Effect of fly-ash on the exchangeable $\mathrm{Ca}$ is due to the higher content $\mathrm{CaO}$ than the other cations ( $\mathrm{Na}, \mathrm{K}$ and $\mathrm{Mg}$ ) of fly-ash, so that when flyash is added to soil, it will increase the availability of $\mathrm{Ca}$ in soils. This is consistent with the study of Kishor et al. (2009) who reported that exchangeable $\mathrm{Ca}$ is the most dominant cation in soils with fly-ash application

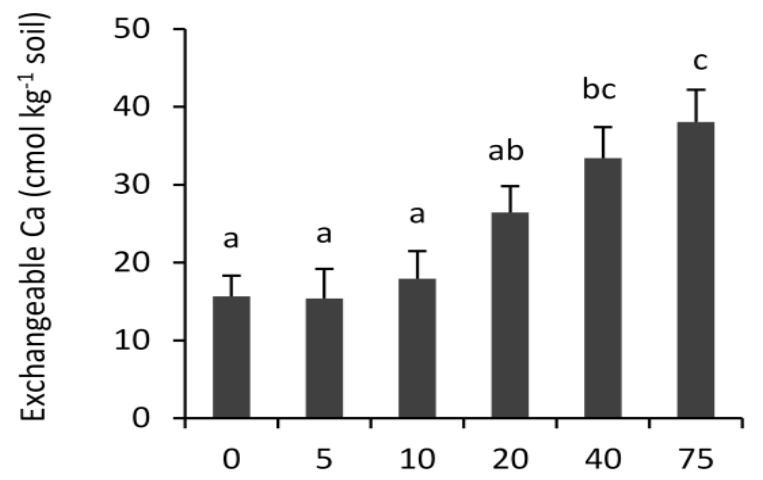

Fly-ash application (ton $\mathrm{ha}^{-1}$ )

Figure 2. Effect of fly-ash application on exchangeable $\mathrm{Ca}$. The vertical bars represent standard deviation $(n=5)$. Similar letters above columns indicate no statistical difference between the treatments based on the LSD test at $P<0.05$. 


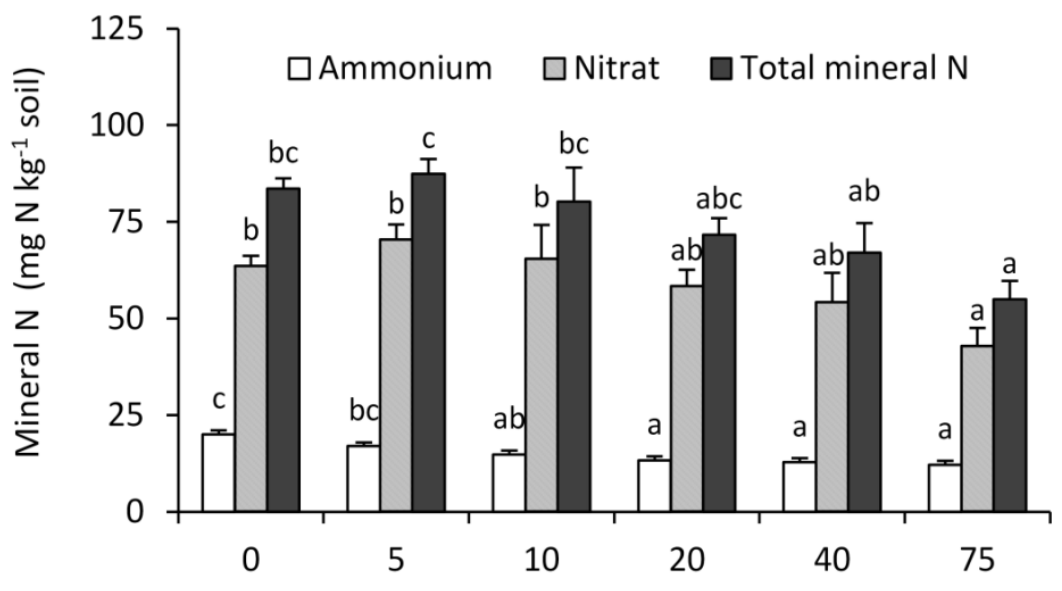

Fly-ash application (ton ha-1)

Figure 3. Effect of fly-ash application on inorganic nitrogen. The vertical bars represent standard deviation $(n=5)$. Similar letters above columns indicate no statistical difference between the treatments based on the LSD test at $P<0.05$.

Concentration of ammonium and nitrate decreased with an increase in the amount of fly-ash application. Concentration of ammonium in the soil decreased from $20.03 \mathrm{mg} \mathrm{N} \mathrm{kg}^{-1}$ to $12.15 \mathrm{mg} \mathrm{N} \mathrm{kg}^{-1}$ soil and concentration of nitrate decreased from 63.61 $\mathrm{mg} \mathrm{N} \mathrm{kg}^{-1}$ soil to $42.83 \mathrm{mg} \mathrm{N} \mathrm{kg}^{-1}$ soil with flyash application (Figure 3). These combinations resulted in reduction in total mineral nitrogen from $83.64 \mathrm{mg} \mathrm{N} \mathrm{kg}^{-1}$ soil to $54.98 \mathrm{mg} \mathrm{N} \mathrm{kg}^{-1}$ soil with the application of fly-ash (Figure 3). Decline in the mineral nitrogen with fly-ash application is due to increased gaseous $\mathrm{N}$ losses through denitrification process with increasing the amount of fly-ash application.

\section{Growth Performance of Rice}

Results of variance analysis showed that fly-ash application influenced significantly the growth and production of rice. Fly-ash application of 5 and 10 tonnes $\mathrm{ha}^{-1}$ improved plant height from $78 \mathrm{~cm}$ to $92-$ $94 \mathrm{~cm}$. However, when the amount of fly-ash application increased to 20-75 tonnes $\mathrm{ha}^{-1}$, plant height did not show significant increases with subsequent increasing the amount of fly-ash application (Figure 4). Similar results were obtained for the number of tiller variable. Without the fly-ash application, the average number of tillers reached only 3 plants per pot. Number of tillers plants increased significantly to 7 plants per pot with the fly-ash application at the rate 5-10 tonnes ha ${ }^{-1}$ (Figure 4).

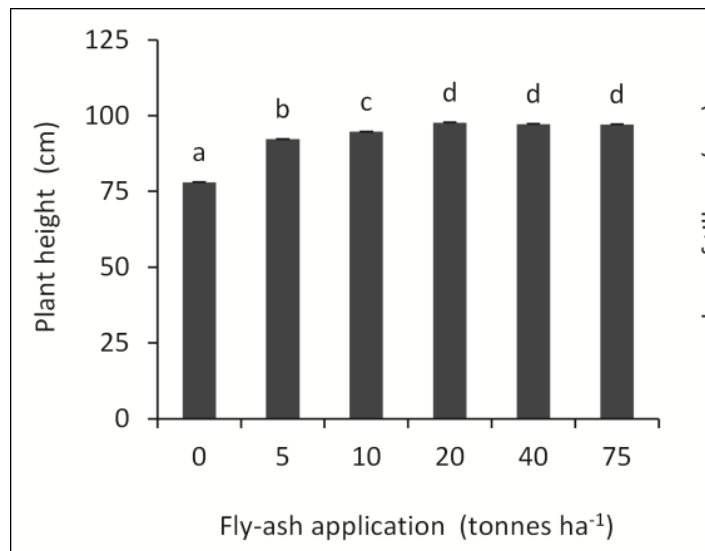

Figure 4. Effect of fly-ash application in plant height (left) and number of tillers

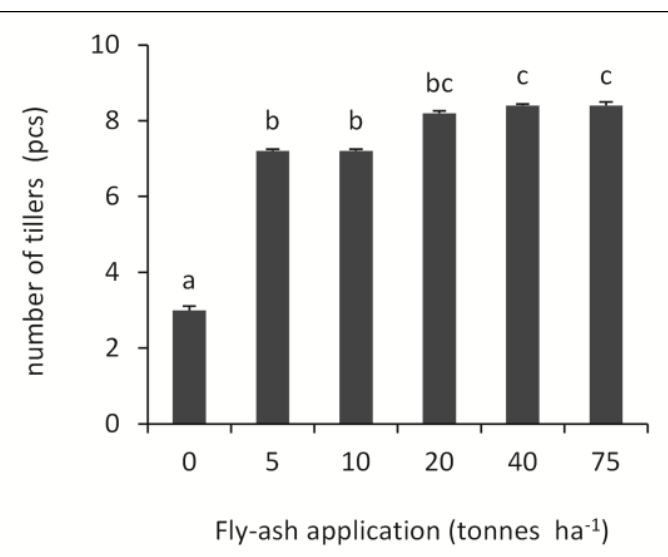

(right). The vertical bars represent standard deviation $(n=5)$. Similar letters above 
columns indicate no statistical difference between the treatments based on the LSD test at $P<0.05$.

Root dry weight of rice plants with flyash applications up to the level of 20 tonnes $\mathrm{ha}^{-1}$ is no different from that without fly-ash application, which is in the range of 1.5 to 3.5 grams per pot (Figure 5). However, when the amount of fly-ash application increased to 40 and 75 tonnes ha ${ }^{-1}$, root dry weight of rice plants increased to 5 grams per pot (Figure 5). In contrast to the root dry weight, stems dry weight of rice with the treatment of 5-20 tonnes ha ${ }^{-1}$ fly-ash application increased to 913 grams per pot from 3 grams per pot at the treatment of without fly-ash application (Figure 5). The highest root dry weight of plants was observed in the treatment of 40 and 75 tonnes ha ${ }^{-1}$ fly-ash application (Figure 5).

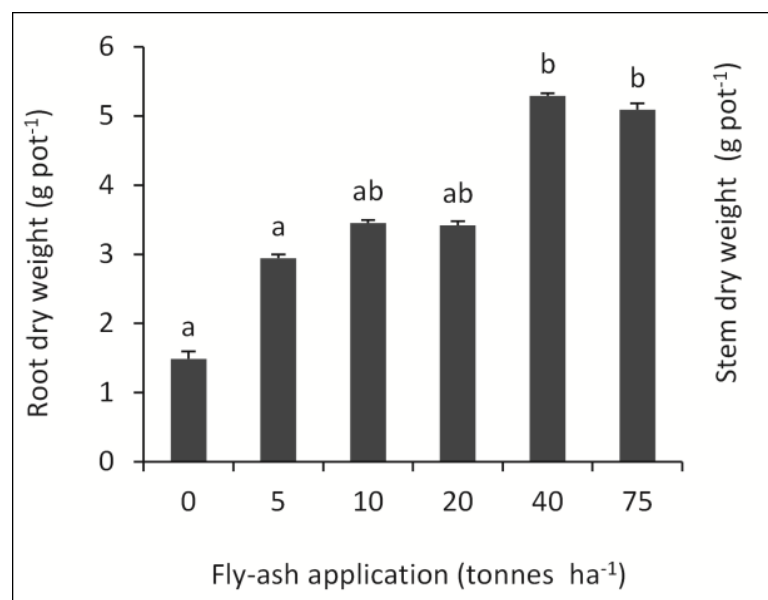

Figure 5. Effect of fly-ash application on root dry weight (left) and stem dry weight (right). The vertical bars represent standard deviation $(n=5)$. Similar letters above columns indicate no statistical difference between the treatments based on the LSD test at $P<0.05$.

Figure 6. Effect of fly-ash application on rice production. The vertical bars represent standard deviation $(n=5)$. Similar letters above columns indicate no statistical difference between the treatments based on the LSD test at $P<0.05$.

Rice production also increased by flyash application. Grain dry weight of rice without fly-ash application is 3.5 grams of pot 1 , increased more than $200 \%$ (11.4 $\left.\mathrm{g} \mathrm{pot}^{-1}\right)$ with 5 tonnes ha $^{-1}$ of fly-ash application. When the amount of fly-ash application increased to 20 tonnes ha ${ }^{-1}$, grain dry weight increased by $280 \%\left(13.4 \mathrm{~g} \mathrm{pot}^{-1}\right)$. Moreover, there is an increase by $300 \%$ in the grain dryweight (14.5 g pot-1) with 75 tonnes ha ${ }^{-1}$ of fly-ash application (Figure 5).

Increases in the growth and production of rice were attributed to increasing the amount of nitrogen, phosphorus and potassium absorbed by rice. Nitrogen uptake by rice in the treatment of without fly-ash application was $84.39 \mathrm{mg} \mathrm{N}$ pot $^{-1}$, increased

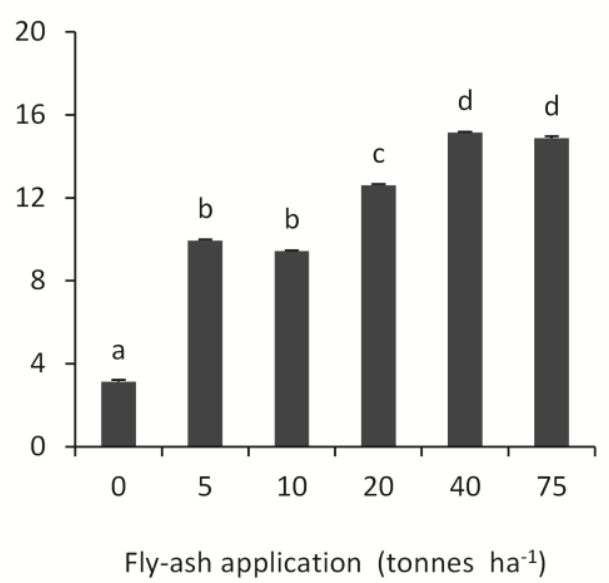

by $16-38 \%$ with $5-75$ tonnes ha ${ }^{-1}$ of fly-ash application. Phosphorus and potassium uptake by rice increased by $6-70 \%$ and 17 $128 \%$, respectively, with the similar amount of fly-ash application (data not shown).

Increase in nutrient uptake followed by increase in the growth and production of rice may due to changes in the characteristics of the soil with the application of fly-ash. The addition of fly-ash to soils accelerate the process of mineralization of organic matter (Khan and Khan, 1996), thus increasing the availability of nitrogen. Lee et al. (2007) in the study of changes in the availability of $P$ in soils with 120 tonnes ha ${ }^{-1}$ of fly-ash application in South Korea reported that the increase in $\mathrm{P}$ in the soils due to the increase in the $\mathrm{pH}$ of the soil, increasing the amount of silicate and the additional $P$ from coal ash. In this study, we also observed increases in soil $\mathrm{pH}$ from 4.43 at the treatment without fly-ash application to $\mathrm{pH} 5.22-5.41$ with the fly-ash application. Study conducted by Swain et al. (2007) also showed that the fly-ash application increases the uptake of N, P and K by $106-149 \%$. 


\section{CONCLUSION}

Observations on soil chemical properties after fly-ash application showed that the addition of the fly-ash can increase the soil $\mathrm{pH}$, in which increased the amount of fly-ash application to the soil will be followed by increases in soil pH. This result implies that the fly-ash is potential to be used as an alternative lime for soil improvement properties to increase biomass production. Results of the study demonstrated that among the exchangeable cations observed, only exchangeable $\mathrm{Ca}$ increased significantly with fly-ash application, indicating that fly-ash can be used as a source of $\mathrm{Ca}$ for improvement of soil properties. The application of fly-ash also increases the growth and yield of rice.

\section{ACKNOWLEDGEMENTS}

The authors acknowledged the Ministry of Education and Culture, the Republic of Indonesia that was funded this study through the Competitive Grant of Penelitian Unggulan Perguruan Tinggi 2014.

\section{REFERENCES}

Bohn, HL, McNeal BL, O'Connor GA. 2001. Soil Chemistry. $3^{\text {rd }}$ edition. John Willey \& Sons, Inc., New York.

Clark RB, Zeto SK, Ritchey KD, Baligar VC. 2007. Mineral acquisition by maize grown in acidic soil amended with coal combustion product. Communication in Soil Science and Plant Analysis 32:1861-1884.

Comberato JJ, Vance ED, Someshwar AV. 1997. Composition and land application of paper manufacturing residuals. In: Rechcigl J, Mackinnon H. (Eds.) Agricultural Uses of By-products and Wastes. ACS, Washington, DC, pp. 185203.

Department of Agriculture, Province of South Kalimantan. 2007. Data Base of Agriculture 2007. Department of Agriculture, Province of South Kalimantan, Banjarbaru.

Hyup L, Sung Ha H, Hoon Lee C, Book Lee Y. 2006. Fly ash effect on improving soil properties and rice productivity in Korean paddy soils.
Bioresource Technology 97: 1490 1497.

Khan RK, Khan MW. 1996. The effect of fly ash on plant growth and yield of tomato. Environmental Pollution 92: 105-111.

Kishor P, Ghosh AK, Kumar D. 2009. Use of fly ash in agriculture: A way to improve Soil Fertility and its productivity. Asian Journal of Agricultural Research 4: 1-14.

Lee $\mathrm{CH}$, Lee $\mathrm{H}$, Lee YB, Chang HH, Ali W, Kim PJ. 2007. Increase of available phosphorus by fly-ash application in paddy soils. Communications in Soil Science and Plant Analysis 38:1551-1562.

Mittra BN, Karmakar S, Swain DK, Ghosh BC. 2005. Fly ash a potential source of soil amendment and a component of integrated plant nutrient supply system. Fuel 84: 1447-1451.

Saidy AR, Ifansyah H, Yulianti N. 2005. Effeciency of nitrogen fertilizer application on paddy soils with different characteristics. Agroscientiae 12: 196-204 (Indonesian).

Sajwan KS, Paramasivam S, Alva AK. 2007. Effects of different rates of fly ash and sewage sludge mixture amendments on cation availability and their leachability. Journal of Environmental Science and Health Part A 42: 1155-1160.

Swain DK, Rautaray SK, Ghosh BC. 2007. Alkaline coal fly ash amendments are recommended for improving rice-peanut crops. Acta Agriculturae Scandinavica Section B-Soil and Plant Science 57: 201-21. 
